\title{
Condições Higiênico Sanitárias do Peixe Comercializado no Mercado do Peixe de Cachoeira, Bahia, Brasil
}

Rebeca Ayala Rosa da Silva (I,II), Lucas Guimarães Cardoso (I),

Sanmily Santos Damasceno (I), Elaine Araújo de Carvalho (I), Nayara Alves Reis (I), Irana Paim Silva (I), Margarete Alice Fontes Saraiva (I), Norma Suely Evangelista-Barreto Evangelista Barreto (I)

(I) UFRB - Universidade Federal do Recôncavo da Bahia (Rua Rui Barbosa, 710, Centro - Cruz das Almas - Bahia. CEP 44.380-000), (II) UFBA - Universidade Federal da Bahia (Av. Adhemar de Barros, n. 500, Ondina, Salvador, Bahia.)

\section{Resumo}

Fish is a food containing high biological value nutrient, very susceptible to deterioration and may cause health problems due to deficient practices of appropriate commercialization. Thus, the present study aimed to evaluate the hygienic-sanitary conditions of the fish selling free open markets in the city Cachoeira, Bahia. The samples were collected every month between November 2013 to February 2014, in the fish selling free open markets. Twenty one samples were analyzed, 7 fishes and 14 bivalve mollusks processed (seven samples of sururu (Mytella guyanensis) and seven samples of "chumbinho" (Anamalocardia brasiliana)), from six different boxes in the market. Physico-chemical parameters $(\mathrm{pH}$, temperature, ammonia reaction, reaction of hydrogen sulfide) and sensorial characteristics (appearance of the eyes, gills, muscle, skin pigmentation, stiffness of the flesh), and the presence of Vibrio species were evaluated. According to the results of visual inspection, the structural dynamics of the market lies with critical indices of inadequacy when compared to the requirements of the current legislation. Four samples (57.14\%) showed a "regular" classification and $42.86 \%$ presented "good" state of freshness. The muscle fish temperature reached ranging from $27^{\circ} \mathrm{C}$ to $30^{\circ} \mathrm{C}$. For the 
$\mathrm{pH}$ analysis, $71.42 \%$ of the samples showed values from 5.0 to 6.7 , below the minimum quality standards of freshness. The presence of hydrogen sulfide and ammonia were detected in the $71.42 \%$ out of $100 \%$ of fish samples. The presence of Vibrio sp. was detected in the fish samples $(41.6 \%)$ and sururu samples (41.6\%), and a lower incidence in the "chumbinho" samples (16.7\%). Twelve Vibrio sp. were phenotypically identified, highlighting the strains of Vibrio cholerae (2), V. vulnificus (1) and V. mimicus (3), serving as a warning because of its pathogenic potential. The hygienic-sanitary market conditions are below the standards of legislation, which may compromise the quality of the products sold. The fish showed a low degree of freshness, besides the presence of the genus Vibrio sp. associated with human gastroenteritis.

Palavras-Chave: FISH, MICROBIOLOGICAL QUALITY, Vibrio sp. Agência de Fomento: 